\title{
チタン酸アルミニウムの水素による還元についで
}

\author{
功刀雅長** 小西昭夫** 佐藤 健*** 高橋克明****
}

\section{Reduction of Titanium Aluminate Heated in Reducing Atmosphere Containing Hydrogene}

by

\author{
Masanaga Kunugi, Akio Konishi, Takeshi Sato
}

(Department of Industrial Chemistry, Kyoto University)

and Katsuaki TAKAHASHI

(Department of Industrial Chemistry, Okayama University)

The reduction of titanium aluminate $\left(\mathrm{Al}_{2} \mathrm{O}_{3} \cdot \mathrm{TiO}_{2}\right)$ heated at $1500^{\circ} \mathrm{C}$ in various reducing atmospheres containing hydrogene has been studied.

The titanium aluminate is prepared by heating $\mathrm{Al}_{2} \mathrm{O}_{3}-\mathrm{TiO}_{2}$ compacts in air at $1650^{\circ} \mathrm{C}$ for four hours. For the identification of crystal structure in the specimens X-ray diffraction analysis is done with the Norelco type diffractometer, using $\mathrm{Cu} K_{\alpha}$ radiation.

As shown in Fig. 4, X-ray patterns of $\mathrm{Al}_{2} \mathrm{O}_{3} \cdot \mathrm{TiO}_{2}$ heated in different reducing atmospheres containing $H_{2}$ have shown observable shift in the $\left(33^{\circ} 0\right)$ line and the evidence of $\alpha-\mathrm{Al}_{2} \mathrm{O}_{3}$. Under the condition of more stronger reducing atmosphere $\mathrm{X}$-ray patterns show the formations of free $\mathrm{Ti}_{2} \mathrm{O}_{3}$ and $\alpha-\mathrm{Al}_{2} \mathrm{O}_{3}$.

These data lead to the following conclusion for the reduction of $\mathrm{Al}_{2} \mathrm{O}_{3} \cdot \mathrm{TiO}_{2}$; $\mathrm{Al}_{2} \mathrm{O}_{3} \cdot \mathrm{TiO}_{2} \longrightarrow\left(\mathrm{Al}_{2-x} \cdot \mathrm{Ti}_{x}\right) \mathrm{O}_{3} \cdot \mathrm{TiO}_{2}+\mathrm{Al}_{2} \mathrm{O}_{3} \longrightarrow \mathrm{Al}_{2} \mathrm{O}_{3}+\mathrm{Ti}_{2} \mathrm{O}_{3}$.

(Received June 18, 1963)

\section{1. 緒}

Bunting が報告した $\mathrm{Al}_{2} \mathrm{O}_{3}-\mathrm{TiO}_{2}$ 系相律図によると チタン酸アルミニウム $\left(\mathrm{Al}_{2} \mathrm{O}_{3} \cdot \mathrm{TiO}_{2}\right)$ はこの系におけ る唯一の化合物で, 融点の高いこと熱膨張率の小さい 点で注目をあびている耐火物である。しかしながらこ の化合物は還元ふんい気においてはコランダムを遊離 して不安定であるのが大きな欠陷とされている。

そこで, 本研究は $\mathrm{Al}_{2} \mathrm{O}_{3} \cdot \mathrm{TiO}_{2}$ の還元ふんい気での 安定化をはかる基礎的な実験として, まずこの化合物 の還元ふんい気における挙動を追求することとした.

$\mathrm{Al}_{2} \mathrm{O}_{3} \cdot \mathrm{TiO}_{2}$ は斜方晶系に属し格子定数は $\mathrm{a}=3 \cdot 557$, $\mathrm{b}=9 \cdot 436, \mathrm{c}=9 \cdot 648 \AA$ で密度 $=3 \cdot 67$, 屈折率 $=1.975$ $\sim 2 \cdot 015$, 融点 $=1 \cdot 860^{\circ} \mathrm{C}$, 熱膨張率はある温度域では 溶融石英よりも小さい?

なお，永広彰夫，御代健次郎は電融合成チタン酸ア ルミニウムの性質を研究し, 電融ならびに一酸化炭素 の還元状態ではコランダムを遊離して新化合物 $\mathrm{Al}_{2} \mathrm{O}_{3}$ • $3 \mathrm{TiO}_{1 \cdot 8}$ を生ずることを確認している.

* 原稿受付 昭和38年 6 月 18 日

** 正員 京都大学工学部

***** 京都大学工学部

****** 正員 岡山大学工学部
また, 最近にお的る研究としては D.M. William ${ }^{6)}$ は，還元ふんい気における $\mathrm{Al}_{2} \mathrm{O}_{3} \cdot \mathrm{TiO}_{2}$ の挙動を調心 たのではないが，アルミナとチタニアの混合物につい て水素還元ふんい気での $\mathrm{Ti}_{2} \mathrm{O}_{3}$ のアルミナへの固溶現 象を究明している.

\section{2. 試料の合成および実験装置}

還元用試料の $\mathrm{Al}_{2} \mathrm{O}_{3} \cdot \mathrm{TiO}_{2}$ を合成するに先だって出 発原料の種類, 合成温度の差異が合成結果に及ぼす影 響を調べた。

アルミナ原料としては $\alpha$ アアルミナ (粒度 $5 \sim 10 \mu)$, 水酸化アルミニウム (粒度 $5 \sim 10 \mu)$ の 2 種の粉末， タニア原料としてアナターゼ(粒度 $0.2 \sim 0.4 \mu)$, アナ ターゼにルチルの混入したもの（粒度 $5 \sim 15 \mu)$, ルチ ル（粒度 5 10 10 )の 3 種の粉末を使用した。 これらの 原料を組み合わせて $\mathrm{Al}_{2} \mathrm{O}_{3} \cdot \mathrm{TiO}_{2}$ のモル比が $1 / 1$ にな るように 6 種の混合物を作り， $1400^{\circ} \mathrm{C}$ をでの示差熱 分析を行なって反応性を調べた。この結果出発原料の 差異による反応性の大差は認められなかったが，ピー ク面積より $\alpha$ ーアルミナとアナターゼ (一部ルチル)の 混合物の反応性が若干大であった。

また，示差熱分析後のこれら試料についてX線的に 
も検討を加えた。装置は理学電機製ガイガーフレック ス，測定条件は銅対陰極，ニッケルフィルター, 30

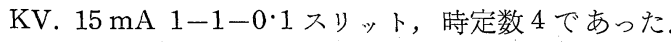

これらの回折結果を Fig. 1 に示す. 各試料とも $\alpha-$ アルミナ，ルチルのほかに新たに生じた $\mathrm{Al}_{2} \mathrm{O}_{3} \cdot \mathrm{TiO}_{2}$ の回折線を示している。この $\mathrm{Al}_{2} \mathrm{O}_{3} \cdot \mathrm{TiO}_{2}$ の合成結果 でも $а$ アアルミナとアターゼ (一部ルチル) の混合物 が若干まさっていた。

次に合成温度を求めるために，この混合物をシリコ ニット電気炉中で $1200,1300,1350,1400^{\circ} \mathrm{C}$ の各温 度に 1 時間空気中焼成を行なった。これら焼成物のX 線回折図を Fig. 2 に示す。この図において 1200 . $1300^{\circ} \mathrm{C} 1$ 時間焼成物にはコランダムとルチルの単独 ピークのみ存在しているのが, $1350^{\circ} \mathrm{C} 1$ 時間の暁成 物では少量のコランダムとルチルを残すのみで，大部 分は $\mathrm{Al}_{2} \mathrm{O}_{3} \cdot \mathrm{TiO}_{2}$ に变化している。さらに, $1400^{\circ} \mathrm{C}$ 1 時間の暁成物になると，この系の反応はほぼ終了し たものと考えられる。

なお， $\mathrm{Al}_{2} \mathrm{O}_{3} \cdot \mathrm{TiO}_{2}$ の合成を確認するため，この混 合物を $1550^{\circ} \mathrm{C} 4$ 時間空気中焼成を行なって焼成物の

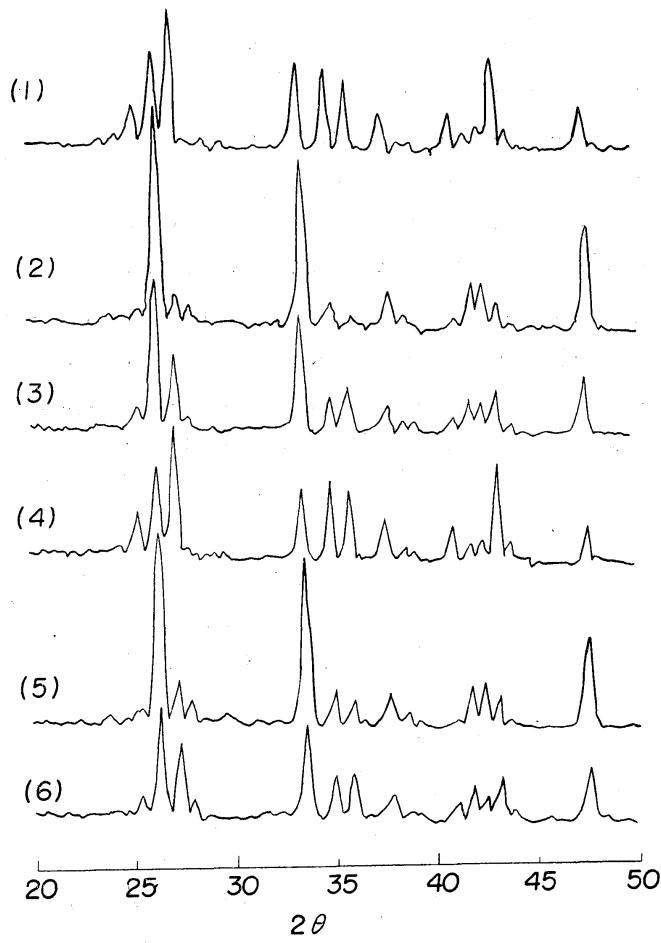

Fig. 1. X-ray diffraction patterns of $\mathrm{Al}_{2} \mathrm{O}_{3}$. $\mathrm{TiO}_{2}$ compacts heated in air up to $1400^{\circ} \mathrm{C}$

(1) $\mathrm{Al}_{2} \mathrm{O}_{3}+\mathrm{TiO}_{2}$ (Anatase)

(2) $\mathrm{Al}_{2} \mathrm{O}_{3}+\mathrm{TiO}_{2}$ (Anatasc + Rutile)

(3) $\mathrm{Al}_{2} \mathrm{O}_{3}+\mathrm{TiO}_{2}$ (Rutile)

(4) $\mathrm{Al}(\mathrm{OH})_{2}+\mathrm{TiO}_{2}$ (Anatase)

(5) $\mathrm{Al}(\mathrm{OH})_{3}+\mathrm{TiO}_{2}$ (Anatase + Rulile)

(6) $\mathrm{Al}(\mathrm{OH})_{3}+\mathrm{TiO}_{2}$ (Rutile)
面間隔の決定を行なった，得られた回折図型はコラン 一ダムとルチルの存在を全く示さず $\mathrm{Al}_{2} \mathrm{O}_{3} \cdot \mathrm{TiO}_{2}$ 化の反 応が完全に終了したものと考えられる．A.S.T.M. カ 一ド記載の $\mathrm{Al}_{2} \mathrm{O}_{3}$ ・ $\mathrm{TiO}_{2}$ の面間隔と焼成物の面間隔と の比較を Table 1 に示すが, 両者はよい一致を示し ている.

これらの結果よりアルミナ原料として $\alpha$ ーアルミナ をチタニア原料としてアナターゼにルチルの混入した ものを使用した. 雨原料の $\mathrm{Al}_{2} \mathrm{O}_{3} \cdot \mathrm{TiO}_{2}$ のモル比を $1 / 1$ にした混合物を固相反応を早めるために, 直径 $25 \mathrm{~mm}$ 高さ $15 \mathrm{~mm}$ の円柱型に成形した後, シリコニット電 気炉に入れて $1550^{\circ} \mathrm{C} 4$ 時間空気中焼成を行ない

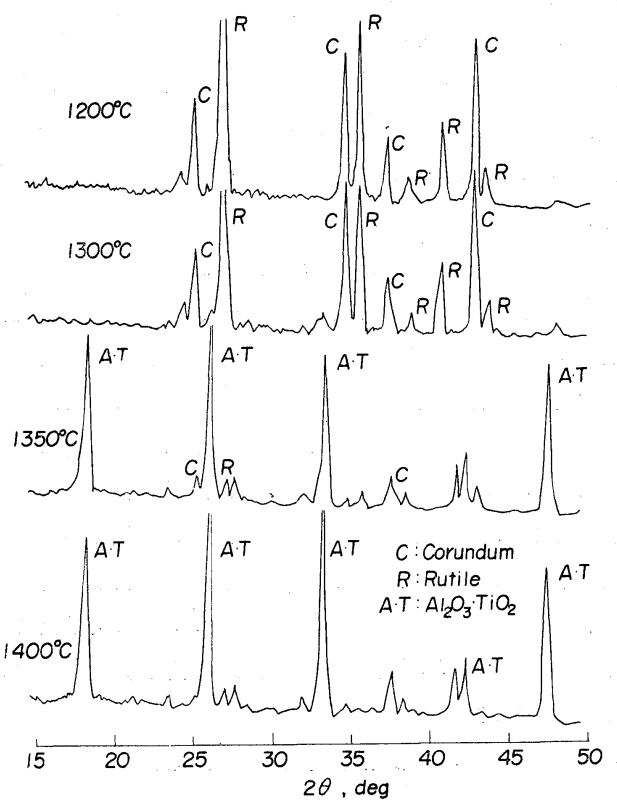

Fig. 2 X-ray diffraction patterns of samples $\mathrm{Al}_{2} \mathrm{O}_{3}+\mathrm{TiO}_{2}$ (Anatase-rutile mixture) heated in air for one hons at four different temperature

Table 1 X-ray diffraction data for $\mathrm{Al}_{2} \mathrm{O}_{3} \cdot \mathrm{TiO}_{2}$

\begin{tabular}{c|c|c|c|c}
\hline $\begin{array}{c}\text { After A.S.T.M. } \\
\mathrm{d}\end{array}$ & $\begin{array}{c}\text { Exp. Data } \\
\text { (A) }\end{array}$ & $\begin{array}{c}\text { After A.S.T.M. } \\
\text { (A) }\end{array}$ & $\begin{array}{c}\text { Exp. Data } \\
\text { (A) }\end{array}$ & $\begin{array}{c}\text { d } \\
\text { (A) }\end{array}$ \\
\hline- & 5.22 & - & 1.787 \\
- & 4.81 & 1.690 & 1.687 \\
4.72 & 4.72 & 1.609 & 1.605 \\
3.36 & 3.36 & 1.581 & 1.578 \\
2.66 & 2.66 & - & 1.571 \\
2.36 & 2.36 & 1.55 & 1.550 \\
2.14 & 2.145 & 1.522 & 1.520 \\
2.11 & 2.117 & 1.487 & 1.488 \\
1.901 & 1.901 & - & 1.481 \\
1.796 & 1.798 & 1.452 & 1.449 \\
\hline
\end{tabular}


$\mathrm{Al}_{2} \mathrm{O}_{3} \cdot \mathrm{TiO}_{2}$ の還元用試料とした。なお，モル比 $1 / 1$ の試料では焼きしまりにくいので，さらに 2 モルの チタニアを加えて $\mathrm{Al}_{2} \mathrm{O}_{3} \cdot \mathrm{TiO}_{2}=1 / 3$ の試料も同じ条 件で筧成し, $\mathrm{X}$ 線分析の結果 $\mathrm{Al}_{2} \mathrm{O}_{3} \cdot \mathrm{TiO}_{2}$ と遊離のル チルが存在することを確認できたので，同様に還元試 料として以下の実験に供することとした.

本実験のために試作したシリコニット水素還元炉の 概略図を Fig. 3 に示す。炉心管として HB 質燃焼管 $(35 \mathrm{~mm} \phi \times 1000 \mathrm{~mm})$ を用い，これを同質の $50 \mathrm{~mm} \phi$ $\times 1000 \mathrm{~mm}$ の燃焼管に入れて二重管とした，外管の 両端に硬質ガラスのキャップを取り付的て水冷し，炉 心管を 6 本のシリコニット発熱体で取り囲み, 温度の 均一性老計った。炉内にはいる水素ガスはあらかじめ ピロガロール，濃硫酸，菏性カリ，シリカゲル中をと おって送りガスの流量は石けん膜流量計によって 600 $\mathrm{cc} / \mathrm{min}$ とした．俩内中心部の温度は炉の上部より挿 入した PtRh6-PtRh30 熱電対により補正に基づいて 求めた。

\section{3. 実 験 方 法}

前述のシリコニット水素還元炉を用いて試料の還元 を行なったが，この場合還元の進行度はふんい気の水 素の濃度, 還元温度および還元時間によって当然影響 されるものである。したがって，本実験では還元温度 のみを $1500^{\circ} \mathrm{C}$ 一定とし，水素を窒素で適当な濃度に 希釈したり，あるいは還元時間を变える方法によった。 便宜上，これらの還元度合を弱還元，中還元，強還元 と称し，それぞれにおける $\mathrm{Al}_{2} \mathrm{O}_{3} \cdot \mathrm{TiO}_{2}$ の挙動を調べ， さらに $\mathrm{Al}_{2} \mathrm{O}_{3} \cdot \mathrm{TiO}_{2}$ 還元物の再酸化過程についての実 験も行なった。

\section{4. 実験結果ならびに考察}

\section{（I）弱還元の実験}

還元試料中の $\mathrm{Al}_{2} \mathrm{O}_{3} \cdot \mathrm{TiO}_{2}=1 / 3$, 試料が全面から水 素の均一拡散を受けるように炉内においた。還元条件 は水素を窒素で 10 倍に希釈した気流中で $1500^{\circ} \mathrm{C} 30$ 分焼成とした，試料側面からの還元の影響を除くため に焼成物より直径 $10 \mathrm{~mm}$, 高さ $15 \mathrm{~mm}$ の円柱を切り 出し, 表面より中心までを 7 層に分けてそれぞれを $\mathrm{X}$ 線分析した。

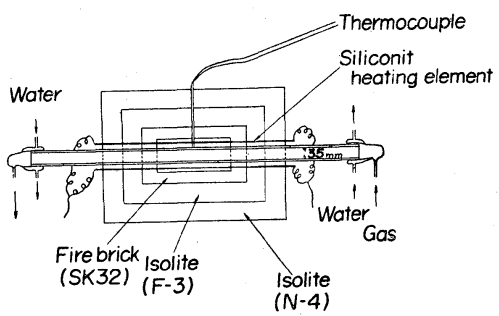

Fig. 3 Schematic drawing of a siliconit reduction furnace
この回折図型のうち， $2 \theta$ の值 $32 \sim 37^{\circ}$ の部分に注 目して見ると，還元の進行につれて遊離のコランダム は増加するが，遊離のルチルは逆に減少し， $\mathrm{Al}_{2} \mathrm{O}_{3}$. $\mathrm{TiO}_{2}$ の回折線は次第にくずれていく，遊離のルチル の回折線強度が還元に伴って隇少する事実よりルチル は還元されて $\mathrm{Ti}^{3+}$ の状態で $\mathrm{Al}_{2} \mathrm{O}_{3} \cdot \mathrm{TiO}_{2}$ かコランダム に固溶したものと考えられる.しかしながら遊離の二 ランダムの面間隔には，ほとんど变化が認められぬの で遊離のルチルは $\mathrm{Al}_{2} \mathrm{O}_{3} \cdot \mathrm{TiO}_{2}$ に固溶して格子不整を 生じたものと推定される。

\section{(II) 中還元の実験}

還元試料中の $\mathrm{Al}_{2} \mathrm{O}_{3} / \mathrm{TiO}_{2}=1 / 1$, 還元条件は水素を 窒素で 6 倍， 3 倍に希釈したガスならびに水素のみの 気流中で $1500^{\circ} \mathrm{C} 1$ 時間焼成とした.

これらの還元物はいずれも黒色を呈し，X線回折図 型の一部を Fig. 4 に示す。この図に括ける $2 \theta=33 \cdot 5^{\circ}$ 付近の回折線は $\mathrm{Al}_{2} \mathrm{O}_{3} \cdot \mathrm{TiO}_{2}$ の (023) 面のもので, $2 \theta$ $=35^{\circ}$ 付近の回折線はコランダムの (104) 面の回折線 である。この図より還元ガスの濃度が増すにつれて， はじめの試料には存在しなかった遊離のコランダムが 次第に増加し, $\mathrm{Al}_{2} \mathrm{O}_{3} \cdot \mathrm{TiO}_{2}$ の回折線強度は次第に減 少しているのは明らかである。ささらにこれらの回折線 を精密測定すると, 還元度が增すにつれて $\mathrm{Al}_{2} \mathrm{O}_{3} \cdot \mathrm{TiO}_{2}$ の面間隔は増大するが，ニランダムの面間隔はほとん ど変化せぬことが判明した。

以上の結果から $\mathrm{Al}_{2} \mathrm{O}_{3} \cdot \mathrm{TiO}_{2}$ は還元されるにつれて 格子中の $\mathrm{Al}^{3+}$ イオンを放出するのは明らかであるが， この場合，還元ふんい気であることから固溶するチタ ンは $\mathrm{Ti}^{3+}$ の状態であると考えられる。また，遊離し たコランダムの面間隔が純粋のコランダムの面間隔と 一致している事実より放出される際 $\mathrm{Ti}^{3+}$ 在伴わない
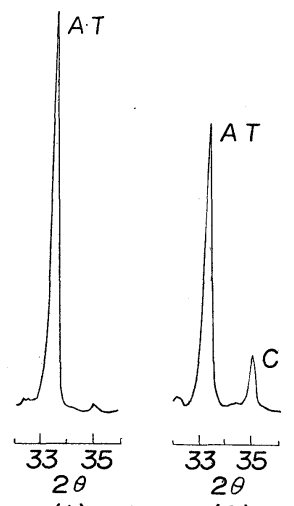

C. Corundum

A.T. $\mathrm{Al}_{2} \mathrm{O}_{3} \cdot \mathrm{TiO}_{2}$
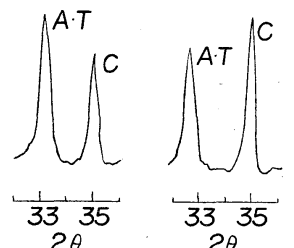

(2)

(4)

Fig. $4 \mathrm{X}$-ray diffraction patterns of $\mathrm{Al}_{2} \mathrm{O}_{3}$. $\mathrm{TiO}_{2}$ heated at $1500^{\circ} \mathrm{C}$ under different reducing conditions

(1) $\mathrm{Al}_{2} \mathrm{O}_{2} \cdot \mathrm{TiO}_{2}$

(3) Heated in $2 \mathrm{~N}_{2}+\mathrm{H}_{2}$

(2) Heated in $5 \mathrm{~N}_{2}+\mathrm{H}_{2}$

(4) Heated in $\mathrm{H}_{2}$ 
ことが判明した。

\section{(III) 強還元の実験}

還元試料中の $\mathrm{Al}_{2} \mathrm{O}_{3} / \mathrm{TiO}_{2}=1 / 3$, 還元条件は還元力 を強めるために試料を黒鉛ボートに入れて水素のみの 気流中で $1500^{\circ} \mathrm{C} 8$ 時間焼成とした。 また，別にチタ ニア単味も同じ条件で還元した.

$\mathrm{Al}_{2} \mathrm{O}_{3} / \mathrm{TiO}_{2}=1 / 3$ の還元焼成物の中心部は黒色, 外 周部は紫色を旺して 2 層に分離したが，チタニア単味 の還元焼成物は一様な紫色を呈した。

これらのX線回折図型を Fig. 5 に示す. 中心の黒 色部分はコランダムとアノソバイト $\left(\mathrm{Ti}_{2} \mathrm{O}_{3} \cdot \mathrm{TiO}_{2}\right)$ に 相当する回折線からなっており，外周部の紫色部分は 遊離のコランダムの回折線とテタニア単味の強還元に よって生ずる $\mathrm{Ti}_{2} \mathrm{O}_{3}$ の回折線とからなっていることが 判明した。

黒色部分については $\mathrm{Al}_{2} \mathrm{O}_{3} \cdot \mathrm{TiO}_{2}$ の還元物が格子中 の $\mathrm{Al}^{+3}$ イオンをすべて放出してその格子点位置に

$\mathrm{Ti}^{3+}$ を置換固溶させるとすれば，アノソバイトになる と考えられる.

そこで得られた黒色部分の面間隔を A.S.T.M カー ド記載のアノソバイトならびに $\mathrm{Al}_{2} \mathrm{O}_{3} \cdot \mathrm{TiO}_{2}$ の面間隔 と比較したが，強還元物の間面隔は $\mathrm{Al}_{2} \mathrm{O}_{3} \cdot \mathrm{TiO}_{2}$ より もむしろアノソバイトに類似していた。また，紫色部 分については $\mathrm{Al}^{3+}$ を遊離して生じたアノソバイトが さらに還元されて $\mathrm{Ti}_{2} \mathrm{O}_{3}$ に变化したものと考えられる.

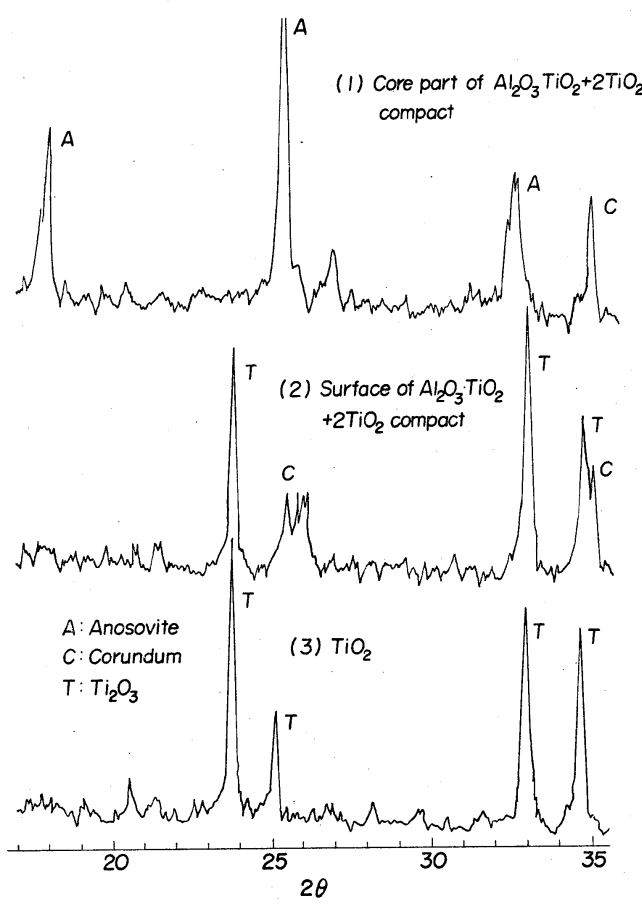

Fig. 5 X-ray diffraction patterns of $\mathrm{Al}_{2} \mathrm{O}_{3}$. $\mathrm{TiO}_{2}+2 \mathrm{TiO}_{2}$ and $\mathrm{TiO}_{2}$ heated at $1500^{\circ} \mathrm{C}$ in $\mathrm{H}_{2}$ for 8 hours

\section{(IV) $\mathrm{Al}_{2} \mathrm{O}_{3} \cdot \mathrm{TiO}_{2}$ 還元物の再酸化過程の実験}

還元焼成した試料を空気中で再加熱すれば，酸化に よる变化がおこることは想像される。そこで 2 種の還 元試料を用いて，これらの酸化過程を示羑熱分析およ び熱天びん法により追跡した.

(i) 示差熱分析の結果 試料には $\mathrm{Al}_{2} \mathrm{O}_{3} \cdot \mathrm{TiO}_{2}$ を $1500^{\circ} \mathrm{C} 20$ 時間 10 倍に希釈した水素気流中で還元焼成 したもの[A]および $1500^{\circ} \mathrm{C} 15$ 時間水素中で還元焼成 したもの[B]の 2 種を用いた。

使用した装置は島津製自記示差熱分析装置で炉の加 熱速度は $10^{\circ} \mathrm{C} / \mathrm{min}$ とし, 室温より $1000^{\circ} \mathrm{C}$ な゙の熱 分析を行なった。

この結果を Fig. 6 に示す。この図より酸化反応は

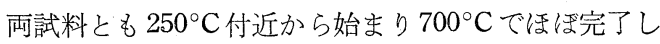
ていることがわかる。しかるに両試料とも $870^{\circ} \mathrm{C}$ 付近 から $1000^{\circ} \mathrm{C}$ にかけて再度発熱反応がみられるが，こ れは何に起因するものであるかは明らかでない.

熱分析をおえた試料を X線分析したところ[A]試料 においては少量の $\mathrm{Al}_{2} \mathrm{O}_{3} \cdot \mathrm{TiO}_{2}$ が存在するが，ほとん どルチルとコランダムに分離していた：[B]試料にお いては $\mathrm{Al}_{2} \mathrm{O}_{3} \cdot \mathrm{TiO}_{2}$ の存在が全〈認められなかった。

(ii） 熱天びん法による結果 上の 2 試料を用いて 熱天びんにより酸化増量を調べた，装置は先の示差熱 分析装置に付加されたもので $10^{\circ} \mathrm{C} / \mathrm{min}$ の加熱速度と し, $1000^{\circ} \mathrm{C}$ ず测定した.

この結果を Fig. 7 に示す。酸化増量は[A]試料は

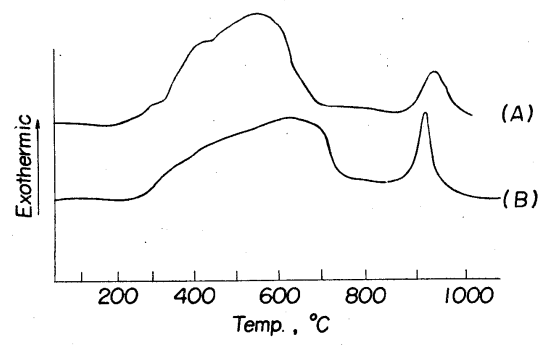

Fig. 6 Differential thermal analyses of $\mathrm{Al}_{2} \mathrm{O}_{3} \cdot \mathrm{TiO}_{2}$ samples

(A) $\mathrm{Al}_{2} \mathrm{O}_{3} \cdot \mathrm{TiO}_{2}$ Heated in $9 \mathrm{~N}_{2}+\mathrm{H}_{2}$ at $1500^{\circ} \mathrm{C}$ (B) $\mathrm{Al}_{2} \mathrm{O}_{3} \cdot \mathrm{TiO}_{2}$ Heated in $\mathrm{H}_{2}$ at $1500^{\circ} \mathrm{C}$

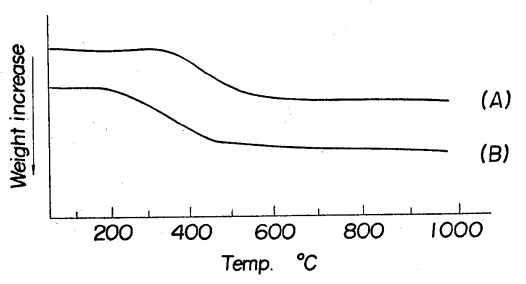

Fig. 7 Thermogravimetric analyses of $\mathrm{Al}_{2} \mathrm{O}_{3}+\mathrm{TiO}_{2}$ samples

(A) $\mathrm{Al}_{2} \mathrm{O}_{3} \cdot \mathrm{TiO}_{2}$ heated in $9 \mathrm{~N}_{2}+\mathrm{H}_{2}$ at $1500^{\circ} \mathrm{C}$

(B) $\mathrm{Al}_{2} \mathrm{O}_{3} \cdot \mathrm{TiO}_{2}$ heated in $\mathrm{H}_{2}$ at $1500^{\circ} \mathrm{C}$ 
$330^{\circ} \mathrm{C},[\mathrm{B}]$ 試料は $250^{\circ} \mathrm{C}$ 付近から始まり，ともに $600^{\circ} \mathrm{C}$ 付近て増量はとまり, 示差熱分析の結果と一致 している.このように示差熱分析にお汁る $900^{\circ} \mathrm{C}$ 付近 の発熱反応に対応する重量変化はみられず，この反応 は重量変化を伴わない構造上の変化に基づくものと考 えられる。

\section{5. 結言}

以上，これらの実駼結果より $\mathrm{Al}_{2} \mathrm{O}_{3} \cdot \mathrm{TiO}_{2}$ は水素還 元によって，まず格子中の $\mathrm{Al}^{3+}$ を放出し格子中の $\mathrm{Ti}^{4+}$ または遊離の状態で存在する $\mathrm{Ti}^{4+}$ が還元されて 生じた $\mathrm{Ti}^{3+}$ がこの $\mathrm{Al}^{3+}$ に代って置換固溶すると考え
られる。

さらに還元が進むと $\mathrm{Al}_{2} \mathrm{O}_{3} \cdot \mathrm{TiO}_{2}$ はアノソバイトに 近い構造にまで置換固溶が進み,ついには $\mathrm{Ti}^{4+}$ は $\mathrm{Ti}^{3+}$ に還元されてコランダムと $\mathrm{Ti}_{2} \mathrm{O}_{3}$ とに分解する ものと考光られる。

\section{参考文 献}

1) E.N. Bunting, J. Res. Natl. Bur. Stand., 11, 719 (1933) 2) 吉木交平, 耐火物工学, 451 (1962)

3）永広彰夫, 御代健次郎, 旭硝子研究報告, 3, 2, 148 (1953)

4) " , " " , 4, 2, 133 (1954)

5) " " " $"$, 5, 2, $136(1955)$

6) D.M. William, J.Am. Cer. Soc., 46 [1] 54 (1963)
(649頁より)

\section{6 型不銹鋼の蓋付薄肉円筒のクリープ破断性質}

(Capped End Thin-Wall Tube Creep-Rupture Behavior far Type 316 Stainless Steel) by G.H. Rowe, J.R. Stewart and K.N. Burgess, Trans. ASME, Series D, pp. 71 86 (Mar. 1963) 図 31

316 型不銹鋼を用いて, $1350^{\circ} \mathrm{F} \sim 1650^{\circ} \mathrm{F}$ で単軸引 張試験と薄肉円筒試験片による内圧破断試験を行ない， それらの相関狌を調べたものである。試験片は $6 "$ の 棒の軸, 接線, 半径方向上り削り出され, 材料のクリ 一プ破断性質の等方性と冶金学的な安定性が確認され た。円筒試験片はガスにより内圧を加えられ，その大 部分は Ar ガスが，一部は空気が用いられた。

試験結果によれば，破断寿命は最大応力説 (max, stress criterion)に従うようである。円筒試験片の破 断時間が単軸引張試験片の第 3 期クリープの開始時間 に一致する時は，他の破断基準（たとえば，相当応力 effective stress に基づくもの）も適用しうることが示 された。本論文の実験では，円筒試験片に第 3 期クリ ープが現われず，そのために破断伸びは小さくなった。 クリープ速度に対してはSoderbergが修正した Mises criterion（通常用いられるひずみ速度に対する Mises, の式）がよく適合することが示された。しかし 1500 ${ }^{\circ} \mathrm{F}$ での試験結果を統計的に整理した結果, 単軸引張 試験片と円筒試験片の平均の相当最小クリープ速度は 低応力では明らかにわずかに相違することが得られた。

(鈴木房幸)

クリープ状態下の回転円盤における遷移期間の影響

(Effects of the Transient Period in Evaluating
Rotating Disk Tests under Creep Conditions) by A.M. Wahl Trans. ASME, Series, D pp. 66 70 (Mar. 1963) 図 7

高温における円艋の hot spin test とその解析につ いては，この筆者はすでに幾つかの論文を報告してい る. (Jour. Appl. Mech. Vol. 21, 22, 1954，1956 等) これらの論文ではクリープの遷移期間は無視されて計 算が行なわれたが，長時間試験結果より最初の弾塑性 応力状態から定常クリープ応力分布に移行する間の遷 移期間も考慮されねばならないことが認められた。

本論文は，回転円盤の長時間クリープ試験に及隹す 初期遷移期間の影響を解析したものである。解析には Mises と Tresca の criterion とおのおのに対応する flow rule を組み合わせたものを採用し，前者は時間 硬化説に基づき，後者は時間硬化とひずみ硬化説に基 づいて遷移クリープを計算した．上記の前報で試験し た $\mathrm{Cr}$ 鋼の円艋 $\left(1000^{\circ} \mathrm{F}\right)$ につき計算し接線応力分布 および内径でのクリープひずみを求めている. Tresca criterion によれば時間硬化とひずみ硬化説の差は小 さく, 内径での応力は約 1 時間で定常状態に達し, 遷 移期間は全クリープ変形に大きい影響を及ぼさないこ とが示された。これはクリープ変形が大きい時である が，弾性ひずみと同程度である場合には，もちろん， 遷移期間の影響を含める必要がある. Mises criterion によるひずみの計算值は実験結果に比べて小さ過ぎ， 設計上危険側となる。Tresca または Tresca-Mises 型の criterion によるものが実験值(変形)によりよく 一致することが示されている.

(鈴木房幸) (668 頁へ) 